\title{
ANALISIS MODEL FUNDRAISING ZAKAT, INFAK DAN SEDEKAH DI LEMBAGA ZAKAT
}

\author{
NildaSusilawati \\ Institut Agama Islam Negeri Bengkulu \\ Email: nildaqila@gmail.com
}

\begin{abstract}
Fundraising model of zalcat, infaq and alms on zakat institutions is done with different models, in accordance with the institutional management system, human resources and the scope of zaltat institutions are located. Fundraising model of zakat, infaq and alms is crucial to the success of institutions in collecting zakat, infak and alms from the community. In general, the model can be divided into two namely directly muzakki zakat institute to pay zakat and indirectly such as through the transfer, event, outlets, and application systems and zakat information. both models are very effective in collecting zakat, although it still needs improvement and development in its implementation in order to facilitate muzakki and able to attract the attention of muzakki in distributing zakat, infak and alms.
\end{abstract}

Keywords: Model fundraising zakat, infaq and alms

Abstrak: Model Fundraising zakat, infak dan sedekah pada lembaga zakat dilakukan dengan model yang berbedabeda, sesuai dengan sistem pengelolaan lembaga, sumber daya manusia dan lingkup wilayah lembaga zakat itu berada. Model fundraising zakat, infak dan sedekah sangat menentukan keberhasilan lembaga dalam menghimpun zakat, infak dan sedekah dari masyarakat. Secara umum model yang dilakukan dapat dibagi menjadi dua yaitu secara langsung muzakki mendatangi lembaga zakat untuk membayar zakat dan secara tidak langsung seperti melalui transfer,event, gerai,dan sistem aplikasi dan informasi zakat. kedua model ini sangat efektif dalam pengumpulan zakat, walaupun masih perlu perbaikan dan pengembangan dalam pelaksanaannya agar memudahkan muzakki dan mampu menarik perhatian muzakki dalam menyalurkan zakat, infak dan sedekah.

Kata Kunci: Model fundraising zakat, infaq dan sedekah

\section{A. PENDAHULUAN}

Fundraising zakat, infak dan sedekah merupakan bentuk pengelolaan zakat infak dan sedekah yang dilakukan lembaga zakat, selain melakukan pendistribusian atau pendayagunaan dan melakukan pelaporan terhadap semua aktivitas pengelolaan dana zakat, infak dan sedekah. Semua bentuk pelaporan sebagai bentuk pertanggungjawaban atas pengelolaan dana oleh pengelola zakat di setiap tingkat Badan Amil Zakat Nasional maupun lembaga zakat lainnya.

Pasal 28 Undang-undang nomor 23 tahun 2011 dijelaskan lembaga zakat mempunyai tugas bahwa pengelolaan infaq, sedekah dan dana sosial lainnya adalah selain menerima zakat, BAZNAS atau UPZ juga dapat menerima infak, sedekah, dan dana sosial keagamaan lainnya. Pendistribusian dan pendayagunaan infak, sedekah dan dana sosial keagamaan lainnya sebagaimana dimaksud pada ayat (1) dilakukan sesuai dengan syariat Islam dan dilakukan sesuai dengan peruntukan yang diikrarkan oleh pemberi. Pengelolaan infak, sedekah dan dana sosial keagamaan lainnya harus dicatat dalam pembukuan tersendiri.

Tugas dan tanggung jawab lembaga zakat untuk mengelola zakat yang diatur melalui undang-undang memberikan wewenang bagi pengelolan zakat untuk melakukan tugasnya secara baik. Selain itu wujud dari pengelolaan zakat diambil dari 
ayat al-Qur'an yang menjelaskan tentang kebolehan mengambil zakat dari harta-harta masyarakat yang telah memenuhi kewajiban zakat berupa nisab dan haul sebagimana dalam firman Allah surat atTaubah ayat 103:

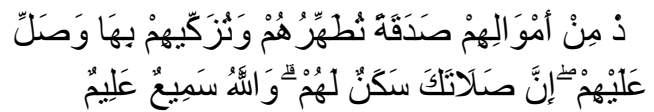

"Ambillah zakat dari sebagian harta mereka, dengan zakat itu kamu membersihkan dan mensucikan harta mereka dan mendoalah untuk mereka. Sesuangguhnya doa kamu itu (menjadi) ketentraman jiwa bagi mereka. Dan allah Maha mendengar lagi Maha mengetahui."(QS. At-Taubah: 103)

Lembaga zakat memiliki peran penting dalam keberlangsungan pengeloaan zakat, mulai dari pengumpulan zakat hingga pendistribusian zakat, infak dan sedekah sebagai lembaga yang diberikan kewenangan untuk mengelola. Kerena itu setiap lembaga harus menerapkan beberapa model pengumpulan zakat untuk mengoptimalisasi pengumpulan harta zakat agar bisa berdaya bagi peningkatan kesejahteraan masyarakat baik itu melalui zakat konsumtif maupun produktif.

Potensi zakat di Indonesia merupakan potensi zakat yang terbesar di dunia, yaitu sebesar 217 triliun rupiah (BAZNAS dan FEM IPB, 2011), namun realisasi penghimpunan zakat nasional tidak sampai
2 persen dari potensi yang ada. Menurut laporan BAZNAS penghimpunan zakat 2014 dalam skala nasional sebesar 3,2 triliun rupiah. Hal ini menunjukkan adanya kesenjangan yang sangat tinggi antara potensi dan realisasi penghimpunan zakat nasional di Indonesia. Pemerintah melalui Instruksi Presiden no. 3 tahun 2014 yang ditujukan kepada seluruh lembaga pemerintah agar memfasilitasi karyawan di instansi masing-masing untuk menyalurkan dana zakatnya melalui BAZNAS. ${ }^{1}$ hal ini memberi ruang yang besar begai lembaga zakat untuk melakukan kerjasama dengan lembaga pemerintah dalam upaya pengumpulan zakat.

Kerjasama yang dilakukan oleh lembaga zakat kepada instansi penerintah dan swasta sangat membantu lembaga zakat dalam pengumpulan zakat. Karena upaya ini memudahkan muzakki dalam menyalurkan zakatnya melalui pemotongan gaji mereka pada setiap bulan dan meringankan tugas pengelola zakat dalam pengumpulan zakat. Selain lebih efisien, dana zakat, infak dan sedekah biasanya akan dibayar muzakki tepat pada waktunya. Hal ini memudahkan pengelola zakat dalam membuat program penyaluran dan pendayagunaan zakat.
${ }^{1}$ Ita Aulia Coryna, Formulasi Strategi Penghimpunan Dana Zakat oleh Badan Amil Zakat Nasional. Repository,sb.ipb.ac.id 
Usaha lembaga zakat untuk menarik masyarakat untuk berzakat, infak dan sedekah serta memberikan informasi tentang tugas dan fungsi lembaga zakat terus dilakukan agar pemahamanan masyarakat yang masih kurang terhadap fungsi lembaga zakat bisa disampaikan melalui sosialisasi sehingga lembaga zakat belum mampu secara maksimal menjalan fungsinya khususnya dalam pengumpulan zakat. Sementara bila diperhatikan dengan potensi zakat yang begitu besar hingga 217 trilian di Indonesia. Dana zakat dapat menjadi sumber dana potensial dalam meningkatkan ekonomi mustahik melalui program zakat produktif.

Melalui undang-undang zakat, lembaga zakat memiliki payung hukum dalam aktivitas pengelolaan zakat, infak maupun sedekah. Namun masih terkendala teknik dalam mengimplementasikan isi masingmasing pasal untuk beberapa wilayah di Indonesia. Dimana untuk menerapkan undang-undang harus juga mendapat dukungan kuat dari segenap pemerintah dan legisatif hingga ke tingkat kabupaten maupun kota, agar lembaga zakat dapat bekerja sama dengan lembaga pemerintah maupun swasta dalam penghimpunan dana zakat. Karena itu perlu dianalisis modelmodel penghimpunan zakat yang telah ada

${ }^{2}$ Manajemen Pengelolaan Zakat, (Jakarta: Direktorat Pemberdayaan Zakat, Direktorat Jendral dan sudah diterapkan di lembaga-lembaga zakat sebagai bahan evaluasi untuk memaksimalkan pelaksanaan fundraisng zakat, infak maupun sedekah.

\section{B. PEMBAHASAN}

\section{Fundraising}

Menurut bahasa fundraising berarti penghimpunan dana atau penggalangan dana, sedangkan menurut istilah fundraising merupakan suatu upaya atau proses kegatan dalam rangka menghimpun dana zakat, infak dan sedekah serta sumber dana lainnya dari masyarakat baik individu, kelompok, organisasi dan perusahaan yang akan disalurkan dan didayagunakan untuk mustahik. $^{2}$

Dari penjelasan di atas penulis menyimpulkan bahwa fundraising adalah sebuah cara untuk mempengaruhi masyarakat agar mau mengeluarkan sedikit penghasilannya untuk melakukan amal kebajkan dalam bentuk pemberian dana atau sumber daya lainnya yang bernilai, untuk diberikan kepada masyarakat yang berhak menerimanya.

Fundraising juga dapat diartikan proses mempengaruhi masyarakat baik perseorangan sebagai individu atau perwakilan masyarakat maupun lembaga agar menyalurkan dananya kepada

Bimmbingan Masyarakat Islam Departemen Agama RI, 2009), h. 65 
sebuah organisasi. Kata mempengaruhi masyarakat mengandung banyak makna: pertama, dalam kalimat diatas mempengaruhi bisa diartikan memberitahukan kepada masyarakat tentang seluk beluk keberadaan OPZ.

Kedua, mempengaruhi dapat juga bermakna mengingatkan dan menyadarkan. Artinya mengingatkan kepada donator untuk sadar bahwa dalam harta dan dimilikinya bukan seluruhnya oleh dari usahanya secara mandiri. Karena manusia bukanlah lahir sebagai makhluk individu saja, tetapi juga memfungsikan dirinya sebagai mahluk sosial.

Kesadaran yang seperti inilah yang diharapkan oleh OPZ dalam mengingatkan para donator dan muzaki. Sehingga penyadaran dengan mengingatkan secara terus menerus menjadikan individu dan masyarakat terpengaruh dengan program dan kegiatan pemberdayaan masyarakat yang dilakukannya.

Ketiga, mempengaruhi dalam arti mendorong masyarakat, lembaga dan individu untuk menyerahkan sumbangan dana baik berupa zakat, infaq dan sedekah dan lain-lain kepada organisasi nirlaba. OPZ dalam melakukan fundraising juga mendorong kepedulian sosial dengan memeperhatikan prestasi kerja annual report kepada calon donator. Sehingga ada kepercayaan dari para calon donator setelah mempertimbangkan segala sesuatunya.

Keempat, mempengaruhi untuk membujuk para donator dan muzaki untuk berinteraksi. Pada dasarnya keberhasilan suatu fundraising adalah keberhasilan dalam membujuk para donator untuk memberikan sumbangan dananya kepada organisasi pengelola zakat. Maka tidak ada artinya suatu fundraising tanpa adanya interaksi.

Kelima, dalam mengartikan fundraising sebagai proses mempengaruhi masyarakat, mempengaruhi juga dapat diterjemahkan memberikan gambaran tentang bagaimana proses kerja, program dan kegiatan sehingga menyentuh dasardasar nurani seseorang. Gambarangambaran yang diberikan inilah yang diharapkan bisa mempengaruhi masyarakat sehingga mereka bersedia memberikan sebagian dana yang dimilikinya sebagai sumbangan dana zakat, infaq, maupun shadaqah kepada organisasi pengelola zakat.

Keenam, mempengaruhi dalam pengertian fundraising dimaksudkan untuk memaksa jika diperkenankan. Bagi organisasi pengelola zakat, hal ini bukanlah suatu fitnah, atau kekhawatiran 
akan menimbulkan keburukan. Tentunya paksaan ini dilakukan dengan ahsan sebagai perintah Allah dalam Al-Qur'an surat At-Taubah ayat 103 .

Ada beberapa hal yang menjadi tujuan dari fundraising bagi sebuah organisasi pengelola zakat adalah pengumpulan dana sesuai dengan istilahnya (fundraising) berarti pengumpulan uang. Namun yang dimaksud disini bukanlah uang saja, tetapi dana dalam arti yang luas. Termasuk didalamnya barang dan jasa yang memiliki nilai materi. Walaupun demikian dana dalam arti uang adalah penting. Mengingat sebuah organisasi nirlaba (OPZ) tanpa menghasilkan dana maka tidak ada sumber daya yang dihasilkan. Sehingga apabila sumber daya sudah tidak ada maka organisasi akan kehilangan kemampuan untuk terus bertahan menjaga kelangsungan hidupnya. Oleh karena itu bisa dikatakan bahwa fundraising yang gagal, meskipun memiliki bentuk keberhasilan yang lain.

a. Menghimpun para muzaki dan donator. OPZ yang baik adalah OPZ yang setiap hari memiliki data pertambahan muzaki dan donator. Sebenarnya yang dibutuhkan adalah pertambahan jumlah dan untuk program pemberdayaan masyarakat beserta operasionalnya. Ada dua hal yang bisa dlakukan oleh OPZ untuk tujuan ini, pertama, menambah jumlah sumbangan dana dari setiap donator dan muzaki, dan kedua, menambah jumlah donator dan muzaki itu sendiri.

b. Meningkatkan rasa citra lembaga juga menjadi salah satu tujuan dari fundraising. Aktifitas fundraising yang dilakukan oleh sebuah organisasi pengelola zakat, baik langsung maupun tidak langsung akan membentuk cara organisasi itu sendiri. Dengan gambaran-gambaran yang diberikan melalui interaksi baik langsung maupun tidak langsung akan menumbuhkan citra rasa yang bersifat positif maupun negative. Dengan citra ini, setiap anggota masyarakat akan mempersepsi organisasi pengelola zakat, yang dilanjutkan dengan mengambil sikap dan menunjukkan prilaku terhadap OPZ jika citra yang tertanam dibentuk para muzaki dan donator terhadap OPZ positif, maka masyarakat akan mendukung, dan bersimpati dengan memberikan sumbangan ZIZ-nya. Namun sebaliknya, apabila citra yang ada didalam bentuk anggota masyarakat terhadap OPZ negative, maka mereka akan menghindari, antisipasi dan mencegah orang untuk memberikan sumbangan dan zakat, 
infaq dan shadaqahnya kepada lembaga.

c. Menjaga loyalitas muzaki dan donator agar tetap memberikan sumbangan dana ZIS-nya kepada OPZ. Walaupun harus dengan pengorbanan untuk memberikan sumbangan dana tersebut. Pengorbanan yang dilakukan muzaki dan donator seolah tidak terasa setelah mendapat imbalan rasa puas dari pengorbanan yang diberikan oleh lembaga tersebut. Jadi tujuan memuaskan donatur adalah tujuan yang bernilai jangka panjang, meskipun kegiatannya dilakukan setiap hari.

d. Kadang-kadang untuk melakukan fundraising, sebuah OPZ membatasi pada orang-orang tertentu. Sehingga dibutuhkan kepanjangan tangan untuk sampai pada donator dan muzaki. Apabila OPZ memiliki citra yang baik dimata masyarakat maka akan banyak simpati dan dukungan yang diberikan kepadanya. Bentuk dukungan dan simpati dari masyarakat terhadap OPZ tidak selamanya berupa dana, akan tetapi ada sebagian yang tidak memiliki kemampuan memberikan dana atau sesuatu sebagai sumbangan ZIS-nya karena ketidakmampuan mereka sebagai donator dan muzaki dalam memberikan dana, memberikan bantuan tenaga dan pemikiran untuk majunya sebuah organisasi pengelola zakat, kelompok-kelompok seperti ini sangat diperlukan oleh OPZ sebagai pemberi kabar dan pemberi informasi kepada setiap orang yang memerlukannya. Dukungan dan simpatisan yang berbentuk informan seperti ini, memudahkan lembaga dalam fundraising. Sehingga semakin banyak relasi dan pendukung sebuah OPZ juga merupakan diadakannya fundraising.

Kegiatan fundraising memiliki 5 (lima) tujuan pokok, yaitu: menghimpun dana , menghimpun donator, menghimpun simpatisan atau pendukung, membangun citra lembaga (brand image), dan memberikan kepuasan pada donator.

Pada awal masa Nabi Muhammad SAW, sumber daya negara islam pada saat itu sangat terbatas sehingga sulit mengatur pengadaan barang-barang untuk public. Dalam pembangunan Masjid Nabawi menggunakan pengadaan dari sumbangan tanah dan tenaga sukarela. Dalam perang tabuk, 30.000 pasukan dan 10.000 ekor kuda sepenuhnya dibiayai oleh sumbangan 
sukarela. Bahkan ada sahabat yang menawarkan untuk membeli sumur agar dapat digunakan umat pada masa kekeringan. Masyarakat islam melakukan hal tersebut karena memiliki motivasi yang kuat tentang ajaran agama. Umar Bin Abdul Aziz sebagai khalifah gemar bersedekah dan wara'. Beliau menjadi seorang zahid yang hanya mencari kehidupan akhirat yang abadi. Secara tidak langsung, hal ini memberikan sumbangsih terhadap faktor-faktor mempengaruhi sistem administrasi serta psikologi pejabat dan para rakyatnya.

Hal mana yang diharapkan dengan hadirnya cetak biru zakat Indonesia adalah membuat konstruksi perzakatan sebagai bingkai dan acuan pengaturan dalam pelaksanaan pengelolaan zakat di indinesia. Siapa yang operasional, siapa yang menjadi pengawas dan siapa yang mengupayakan perundang-undangan zakat sehingga sistem pengelolaan zakat terstruktur, operasi serta sasaran pencapaiannya menjadi terarah dan jelas.

\section{Zakat, Infak dan Sedekah}

Zakat secara harfiah berarti berkah, bersih, baik dan meningkat. ${ }^{3}$ Adapun zakat secara istilah menurut Yusuf

\footnotetext{
${ }^{3}$ Ahmad WarsonMunawir, Kamus Al-Munawir Arab-Indonesia Terlengkap, PustakaProgresif, 1997), h. 577

(Surabaya:
}

Qardhawi adalah sejumlah harta tertentu yang diwajibkan Allah dan diserahkan kepada orang-orang yang berhak.Seperti fakir, miskin, muallaf, amilin, riqab, gharimin, fisabilillah dan ibnusabil yang masuk dalam asnaf. ${ }^{4}$

Zakat merupakan harta tertentu yang dimiliki seseorang yang berupa emas, perak, hasil perniagaan, perkebunan, hasil tambang dan hewan ternak. Selain itu zakat juga bisa berupa zakat penghasilan dari profesi yang dijalankan seseorang seperti PNS, pengacara, dokter, konsultan dan lain-lain. Harta ini disebut zakat mal yang wajib dibayar ketika harta sesorang telah mencapai nisab dan dikeluarkan sesuai dengan kadarnya masing-masing.

Selain zakat mal, terdapat pula zakat fitrah yang wajib dikeluarkan oleh setiap muslim besar dan kecil untuk mensucikan diri. Selain itu zakat juga berfungsi untuk memberikan kebahagiaan bagi mustahik zakat dalam menyambut idul fitri dengan terpenuhinya kebutuhan hidup.

Infak berasal dari kata anfaqa yang berarti mengeluarkan, membelanjakan (harta/uang). Menurut istilah, infak adalah segala macam bentuk pengeluaran (pembelajaan) baik untuk

${ }^{4}$ Yusuf Qardhawi ,FiqhZakat,Terj. Salman Harun, el.al (Jakarta: LiteraAntar Nusa, 2002), h. 37 
kepentingan pribadi, keluarga ataupun yang lain. ${ }^{5}$ Sebagaimana yang tercantum dalam surat al-Baqarah ayat 262:

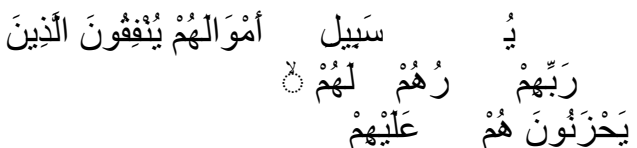

"orang-orang yang membelanjakan hartanya di jalan Allah, kemudian mereka tidak mengira apa yang mereka belanjakan itu dengan cercaan dan dengan tidak menyakiti, mereka memperoleh pahala di sisi Tuhan mereka. Tidak ada kekhawatiran terhadap mereka dan tidak (pula) mereka berduka cita (diakhirat kelak).(QS.Al Baqarah:262)"

Penggunaan lafal zakat dengan segala bentuknya dalam al-Qur'an terulang sebanyak 30 kali dan 27 kali diantaranya digandengkan dengan kewajiban mendirikan sholat. Di samping pemakaian kata zakat dalam berbagai ayat itu, al-Qur'an juga menggunakan kata as-sadaqah dengan makna zakat, seperti dalam surat atTaubah ayat 58, 60 dan 103. Di dalam hadits Rasulullah SAW dijumpai juga lafal as-sadaqah yang berarti zakat, diantaranya hadis:"kurang dari lima wasaq $(652,8 / 653 \mathrm{~kg})$ tidak dikenai zakat..."(HR. Al-Bukhari dan Muslim) dan "Beritahulah mereka bahwa Allah mewajibkan sedekah (zakat) yang diambil dari harta orang-orang kaya..." (HR. Al Bukhari, Muslim, Abu dawud,

${ }^{5}$ Gus Arifin, Zakat, Infak Sedekah, (Jakarta: Elex Media Komputindo, 2016), h. 169

${ }^{6}$ Abdul Aziz Dahlan, dkk, Ensiklopedi Hukum Islam, (Jakarta: Van Hoeve, 1997), h. 1986
at-Tirmizi, an-Nasa'i, Ibnu Majah dan Admad bin Hambali. ${ }^{6}$

Ada delapan asnap yang berhak menerima zakat yaitu fakir, miskin, amil, muamalaf, riqab, al-gharimin, sabilillahdanibnusabil. Mereka berhak atas harta zakat yang dikeluarkan oleh muzakki baik itu bersifat konsumtif maupun produktif.

Ibnu Qasim berpendapat bahwa zakat tidak boleh diberikan kepada orang kaya walaupun berstatus sebagai pejuang di jalan Allah ataupun sebagai amil zakat. Ulama yang memperbolehkan amil yang kaya menerima zakat juga memperbolehkan hakim menerima zakat, dan juga orangorang yang bisa memberikan manfaat kepada umat Islam walaupun mereka kaya. Perbedaan ini disebabkan perbedaan illat, ulama yang melarang orang kaya menerima zakat didasarkan kepada kebutuhan, sedangkan ulama yang membolehkan didasarkan kepada kebutuhan dan manfaat secara umum bahwa amil bermanfaat bagi masyarakat Islam.

Undang-undang nomor 23 tahun 2011 pasal 1 menjelaskan bahwa pengelolaan zakat adalah kegiatan

${ }^{7}$ IbnuRusyd, BidayatulMujatahid,penerjemah Imam Ghazali Said dan Ahmad Zaidun, (Jakarta: PustakaAmani, 2007), h. 616 
perencanaan, pelaksanaan dan pengkoordinasian dalam pengumpulan, pendistribusian dan pendayagunaan zakat. Sementara zakat adalah harta yang wajib dikeluarkan oleh seorang muslim atau badan usaha untuk diberikan kepada yang berhak menerimanya sesuai dengan syariat Islam. Infak adalah harta yang dikeluarkan oleh seseorang atau badan usaha di luar zakat untuk kemaslahatan umum. Sedekah adalah harta atau nonharta yang dikeluarkan oleh seseorang atau badan usaha diluar zakat untuk kemaslahatan umum. Lembaga amil zakat (LAZ) adalah lembaga yang dibentuk masyarakat yang memiliki tugas membantu pengumpulan, pendistribusian dan pendayagunaan zakat.

Ketiga bentuk harta yang bersumber dari masyarakat berupa zakat, infak dan sedekah harus dikelola secara baik oleh lembaga zakat karena semua harta yang diserahkan masyarakat diharapkan mampu membantu masyarakat lainnya dalam meningktkan kesejakteraan.

\section{Regulasi Zakat di Indonesia}

Regulasi zakat di Indonesia terhitung masih baru bila dibandingkan dengan masa Islam masuk ke Indonesia.

${ }^{8}$ N. Oneng Nurul Bariyah, Dinamika Aspek Hukum Zakat dan Wakaf di Indonesia, jurnal Ahkam Vol. XVI, no. 2 tahun 2016, journal.uinjkt.ac.id
Pada masa penjajahan, Belanda pernah mengeluarkan Bijblad Nomor 1892 tanggal 4 Agustus 1893 tentang kebijakan zakat. Pemerintah Hindia Belanda melarang semua pegawai pemerintah dan priyayi pribumi membantu pelaksanaan zakat. Hal tersebut untuk melemahkan posisi dari kehadiran harta zakat. Larangan tersebut tertuang dalam Bijblad Nomor 6200 tanggal 28 Februari 1905. Setelah di Indonesia merdeka regulasi belum disusun. Dan baru muncul berupa Surat Edaran Kementerian Agama No. A/VII/17367 tahun 1951. Tahun 1964 Kementerian Agama menyusun RUU pelaksanaan Zakat dan Perpu pengumpulan dan pembagian zakat serta pembentukan baitul mal. ${ }^{8}$

Sejarah pengaturan zakat di Indonesia ditandai dengan perjuangan panjang dan tarikan antara kepentingan islamis politik dan kepentingan budaya islamis bahkan kepentingan penjajah kolonial dalam upaya mengatur pengelolaan zakat. ${ }^{9}$ Dan baru tahun 2001 dibuatlah Keputusan Presiden tentang Badan Amil Zakat Nasional yang mengatur tentang pengelolaan zakat oleh lembaga Zakat. Keputusan Presiden RI

${ }^{9}$ Muhammad Aziz, Regulasi Zakat di Indonesia; Upaya menuju Pengelolaan zakat yang Profesional, Jurnal al Hikmah, Vol 4 No. 1 tahun 2014, ejurnal.kopertais4.or.id 
ini memberi angin segar terhadap keterlibatan pemerintah dalam upaya pengelolaan zakat bagi umat islam di Indonesia.

Pada tahun 1999 dikeluarkan Undang-undang Republik Indonesia Nomor 38 Tahun 1999 tentang Pengelolaan Zakat. Undang-undang yang terdiri dari sepuluh bab ini mengatur ketentuan umum tentang pengelolaan zakat, zakat, muzakki, mustahik, agama dan menteri. Kemudian pada bab II mengatur tentang asas dan tujuan zakat. Dimana pengelolaan zakat harus berasaskan iman, taqwa, keterbukaan, dan kepastian hukum sesuai dengan Pancasila dan Undangundang Dasar 1945. Adapun pengelolaan zakat bertujuan untuk meningkatkan pelayanan bagi masyarakat, dalam menunaikan zakat sesuai dengan tuntutan agama; meningkatkan Fungsi dan peranan pranata keagamaan dalam upaya mewujudkan kesejahteraan masyarakat dan keadilan sosial; meningkatkan hasil guna dan daya guna zakat.

Pada bab IV pasal 11 dijelaskan bahwa pengumpulan zakat dilakukan oleh badan amil zakat dengan cara menerima atau mengambil dari muzakki atas dasar pemberitahuan muzakki. Dan badan amil zakat dapat bekerja sama dengan bank dalam pengumpulan zakat harta muzakki yang berada di bank atas permintaan muzakki.

Pada penjelasan pasal 12 ayat 2 dijelaskan bahwa bekerjasama dengan bank dalam pengumpulan zakat adalah memberikan kewenangan kepada bank berdasarkan persetujuan nasabah selaku muzakki untuk memungut zakat harta simpanan muzakki yang kemudian diserahkan kepada badan amil zakat.

Keputusan Presiden Republik Indonesia nomor 8 tahun 2001 tentang Badan Amil Zakat Nasional, terdiri dari 7 bab menguraikan tentang pembentukan dan tugas BAZNAS, jangka waktu dan keanggotaan dimana anggota BAZNAS diangkat untuk satu kali periode selama 3 (tiga) tahun dan hanya dapat diangkat kembali hanya untuk satu kali periode berikutnya, dalam pelaksanaan tugasnya badan pelaksana memperhatikan pertimbangan yang disampaikan yang disampaikan oleh dewan pertimbangan dan hasilnya dilaporkan kepada Presiden dan Dewan Perwikilan Rakyat termasuk laporan hasil pengawasan oleh komisi pengawas,hubungan kerja dengan BAZNAS daerah serta tentang pembiayaan dimana segala pembiayaan dalam pelaksanaan tugas BAZNAS 
dbebankan pada anggaran departemen

Agama.

Pada tahun 2011 dikeluarkan Undang-Undang nomor 23 tahun 2011 tentang Pengelolaan Zakat, pasal 3 dijelaskan bahwa, pengelolaan zakat bertujuan untuk meningkatkan efektifitas dan efisiensi pelayanan dalam pengelolaan zakat dan meningkatkan manfaat zakat untuk mewujudkan kesejahteraan masyarakat dan penanggulangan kemiskinan. Undangundang ini mengatur tentang pengelolaan zakat mulai dari lembaga yang berhak mengelola zakat yaitu Badan Amil Zakat Nasional (BAZNAS), pengumpulan, pendistribusian dan pendayagunaan serta pelaporan atas pengelolaan zakat serta pembiayaan dalam pelaksanaan tugas BAZNAS melalui Anggaran Pendapatan Belanja Negara(APBN) dan hak amil. Pembinaan dan pengawasan, peran serta masyarakat, sanksi administrasi dan pidana bagi pengelola yang dengan sengaja melawan hukum tidak melakukan pendistribusian zakat sesuai dengan ketentuan pasal 25 dipidana dengan pidana penjara paling lama 5 (lima) tahun dan/atau pidana denda paling banyak Rp. 500.000.000 (lima ratus juta rupiah).

Sebagai pedoman pelaksanaan terhadap Undang-undang nomor 23 tahun 2011 dibuatlah Peraturan Pemerintah RI nomor 14 tahun 2014 tentang pelaksanaan Undang-undang nomor 23 tahun 2011 tentang pengelolaan zakat. Pada PP ini merinci dari pelaksanaan pengelolaan zakat yang ada pada masing-masing pasal dalam undang-undang nomor 23 tahun 2011, dalam pelaksanaannya lembaga zakat merujuk pada PP ini.

Sebagai penguatan pelaksanaan pengumpulan zakat, presiden melalui Instruksi Presiden Republik Indonesia nomor 3 tahun 2014 tentang Optimalisasi Pengumpulan Zakat di kementerian/Lembaga, Sekretariatan Jenderal lembaga Negara, Sekretariat Jenderal Komisi Negara, Pemerintah Daerah, Badan Usaha Milik Negara dan Badan Usaha Milik Daerah melalui Badan Amil Zakat Nasional. Intruksi Presiden ini secara tegas menginstruksikan kepada lembaga pemerintah untuk melakukan optimalisasi pengumpulan zakat melalui kerjasama dengan lembaga zakat. Dalam bentuk melakukan registrasi muzakki di lembaga pemerintah dan BUMN, membuat mekanisme teknis pengumpulan zakat, melakukan pengumpulan zakat dan menyempaikan laporan hasil pengelolaan zakat di kementerian atau lembaga pemerintah 
dan BUMN ditembuskan kepada

Presiden dan Menteri Agama.

Beberapa kelemahan yang teridentifikasi dalam pengelolaan zakat di Indonesia antara lain: Pertama, soal kelembagaan. Saat ini belum ada kejelasan fungsi siapa sebagai regulator, siapa sebagai pengawas dan siapa sebagai operator. Kedua, belum ada strategic planning secara nasional baik penghimpunan maupun pendayagunaan. Ketiga, soal mekanisme pelaporan yang hingga saat ini belum ada yang jelas bagi lembaga/amil zakat. Keempat, masalah hubungan zakat dan pajak dalam UU no 38 tahun 1999 disebutkan zakat sebagai pengurang penghasilan kena pajak (PPKP), namun dalam prakteknya belum berjalan dengan baik. Kelima, mengenai sanksi. UU pengelolaan zakat yang ada baru mengatur sanksi bagi pengelola zakat. Padahal seharusnya sanksi diberikan kepada muzakki. Tujuannya untuk mengingatkan terhadap kewajiban muzakki yang tertunda. $^{10}$ Melalui regulasi zakat inilah nantinya semua kelemahan yang terjadi pada lembaga zakat zakat atasi agar fundrasing zakat, infak dan sedekah lebih optimal.

\section{ModelFundrasing Zakat, Infak dan}

\section{Sedekah}

Model merupakan pola atau model dari sesuatu yang dibuat. ${ }^{11}$ Model yang dimaksud adalah kegaitan yang dilakukan dalam pengumpulan dana zakat, infak maupun sedekah. fundrasing yang berarti penghimpunan zakat merupakan usaha dari lembaga zakat untuk mengumpulan harta dari muzakki yang telah mencapai nisab dan haul. Zakat yang bisa berbentuk zakat fitrah maupun zakat mal yang dibayar dari harta tertentu yang dimiliki seseorang. Karena kewajiban membayar zakat tercantum dalam surat al-Fushilat ayat 67 dijelaskan bahwa orang yang tidak menunaikan zakat dikategorikan sebagai orang yang celaka, $^{12}$ sebagaimana firman:

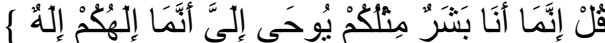

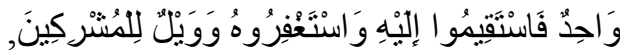

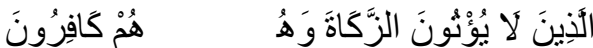

"Bahwasanya aku hanyalah seorang manusia seperti kamu, diwahyukan kepadaku bahwasanya Tuhan kamu adalah Tuhan yang Maha Esa, maka tetaplah pada jalan yang lurus menuju kepad-Nya dan mohon ampunlah kepada-Nya dan kecelakaan besarlah bagi orang-orang yang mempersekutukan-Nya, (yaitu) orangorang yang tidak menunaikan zakat dan

${ }^{10} \mathrm{CiD}, \mathrm{DDR}, \quad$ Pebs-FEUI, Zakat dan Pembangunan; Era Baru Zakat Menuju Kesejahteraan Umat, Jakarta, 2008 dalam Amiruddin, Model-model Pengelolaan Zakat di Dunia Muslim, ejurnal.iaintulungagung.ac.id,h. 160
${ }^{11}$ Em Zul Fajri dan Ratu Aprilia Senja, Kamus Lengkap Bahasa Indonesia, (tt: Fajar Difa Publisher, t.th), h. 572

${ }^{12}$ Gus Arifin, Keutamaan Zakat, Infaq, Sedekah, (Jakarta: Elex Media Komputindo, 2016), h. 6 
mereka kafir akan adanya (kehidupan) akhirat". (QS. Fushilat: 6-7)

Undang-Undang nomor 23 tahun 2011 tentang pengelolaan zakat bab III pasal 21 dijelaskan bahwa dalam rangka pengumpulan zakat, muzakki melakukan penghitungan sendiri atas kewajiban zakatnya. Dalam hal tidak dapat menghitung sendiri kewajiban zakatnya, muzakki dapat meminta bantuan BAZNAS. hal ini dilakukan untuk memudahkan muzakki dalam penghitungan harta bila tidak mengetahui harta yang harus dizakatkan dan tata cara penghitungan harta yang wajib dizakatkan.

Ada beberapa bentuk fundrasing zakat, infak dan sedekah yang dilakukan oleh lembaga zakat yaitu pengumpulan dana zakat, infak dan sedekah secara langsung dari masyararakat. Petugas mendatangi secara langsung calon muzakki untuk dihitung hartanya yang bersumber dari penghasilan usaha, tabungan, atau emas dan perak atau hasil usaha yang dimilikinya. Dengan ketentuan masing-masing dan wajib dikeluarkan sebesar 2,5\%. Sedangkan untuk harta berupa hewan ternak, muzakki tinggal menghitung jumlah hewan ternak yang dimiliki dengan mengeluarkannya sesuai dengan ketentuan, muzakki atau masyarakat mendatangi secara langsung lembaga zakat yang ada dan menyerahkan sejumlah harta yang dimiliki untuk didistribusikan oleh lembaga zakat kepada mustahik zakat. Baik mustahik yang ada disekitar wilayah kerja lembaga zakat maupun dan mustahik zakat yang direkomendasikan secara langsung oleh muzakki yang berada disekitar lingkungan tempat tinggalnya. Menjalin kerjasama dengan instansi pemerintah maupun swasta dalam penghimpunan dana zakat, infak maupun sedekah. Model ini biasanya dilakukan dengan melakukan pemotongan gaji karyawan yang ada di instansi pemerintah maupun swastapada setiap bulannya. Zakat profesi yang dikeluarkan oleh karyawan dihitung dari gaji yang miliki masing-masing dan dibayar setiap bulan oleh bendahara kemudian disetorkan ke lembaga zakat untuk dikelola atau didistribusikan. Selanjutnya, aplikasi online. Penghimpunan zakat melalui aplikasi online yang dimiliki oleh beberapa lembaga zakat. Dengan cara muzakki membuka aplikasi zakat yang tersedia dan membuka laman pembayaran dana zakat, kemudian mengisi data dan jenis harta yang akan dibayar baik berupa zakat, infak maupun sedekah, kemudian muzakki mengisi sejumlah uang yang diinginkan dan mentransfer uang tersebut ke rekening lembaga zakat yang 
dituju. Selain itu, Gerai atau stand zakat.

Beberapa lembaga zakat menempatkan gerai atau stand khusus di pusat perbelanjaan, kantor-kantorBUMN maupun pameran untuk memudahkan akses informasi maupun menyalurkan dana zakat, infak maupun sedekah. Keberadaan gerai atau stand ini lebih praktis karena calon muzakki idak harus mendatangi lembaga zakat secara khusus yang mungkin letaknya agak jauh dari tempat tinggal. Para calon muzakki bisa langsung membayar sejumlah dana zakat, infak maupun sedekah kepada petugas yang ada di gerai atau stand untuk kemudian didistribusikan.

Selain itu juga ada model fundrasing zakat, infak dan sedekah seperti yang dilakukan oleh Dompet Duafa seperti Above the line, yaitu komunikasi melalui media masa sebagai sarana mempromosikan brand atau merk berbasis media elektronik, atau biasa disebut serangan udara, seperti TV, radio, koran, media sosial. Bellow the line, yaitu teknik periklanan yang lebih spesifik dalam memasarkan produk atau layanannya yang dapat berupa aktivitas yang berhubungan atau berinteraksi secara langsung dengan donatur atau biasa disebut dengan serangan darat seperti: Kanvasing merupakan kegiatan marketing yang dilakukan setiap lembaga secara door to door atau bertemu langsung dengan donatur atau masyarakat, sebar brosur, Telemarketing yaitu bentuk direct marceting yang efektif terutama untuk donasi berulang dan mampu memberikan kesan dan interaktif, Directmall adalah pengiriman surat penawaran yang ditujukan langsung kepada para calon donatur melalui email, mobail, sms, faxmail dan BBM dan membuka konter adalah cara komunikasi yang cukup baik untuk dilakukan, dan sasaran berada di titik pusat perbelanjaan dan perkantoran dalam rangka untuk melakukan komunikasi sosialisasi dan edukasi, di samping melakukan seminar dan diskusi publik. $^{13}$

Model fundrasing zakat, infak dan sedekah lainnya seperti Model penghimpunan LAZISMU Ajibarang dilakukan secara langsung dan tidak langsung. Secara langsung seperti direct mail, presentasi langsung, bayar langsung, jemput zakat ke pihak donatur, counter atau gerai, pemotongan gaji karyawan dan kerjasama pemanfaatan atau penyaluran dana zakat. Sedangkan dalam bentuk tidak langsung seperti: 
membuat brosur atau poster iuntuk media komunikasi dan informasi, membuat aksesories seperti bolpoint, stiker dan sebagainya. mengadakan evant, baik yng diadakan mandiri atau bekerjasama dengan lembaga lain. Dan sponshorship sebagai salah satu bentuk kerjasama dengan lembaga atau elemen masyarakat di samping sebagai eksistensi lembaga zakat. ${ }^{14}$

\section{Business Model Canvas (BMC)} melakukan pengumpulan zakat melalui costumer segment, dimana muzakki yang membayarkan zakatnya secara langsung ke BAZNAS, value proposition yaitu BAZNAS memberikan kepada para muzzaki kartu muzakki yang disebut Nomor Pokok Wajib Zakat (NPWZ). NPWZ yang telah dimiliki muzakki tersebut kemudian terhubung ke aplikasi Muzakki Corner. Dengan demikian muzakki dapat dengan mudah mengecek dan mengontrol setoran zakatnya ke BAZNAS. selain itu juga dilakukan model costumer relationships yaitu layanan muzakki, dimana muzakki dapat melakukan konsultasi mengenai zakat dan mengadakan acara khusus bagi para muzakki untuk berkumpul dan

\footnotetext{
${ }^{14}$ Sabar Waluyo, Analisis Strategi Fundraising Lembaga Amil Zakat Infak Shadaqah Muhammadiyah (LAZISMU) Ajibarang Kabupaten Banyumas dalam Mendapatakan Muzaki, 2016, IAIN Purwokerto, h. 79

${ }^{15}$ Dian Purnamasari dan Achmad Firdaus, Analisis strategi Penghimpunan Zakat dengan
}

bertemu. Kegiatan tersebut bertajuk muzakki Gathering. ${ }^{15}$

Model lainnya yang bisa diterapkan dalamfundraising zakat, infak dan sedekah seperti yang dilakukan BAZNAS yaitu melalui Donatur Bawa Donatur (DBD) dan opentable. Donatur Bawa Donatur (DBD) yaitu BAZNAS bekerjasama dengan donatur untuk mengajak rekan, keluarga maupun orang yang mereka kenal untuk menjadi donatur di BAZNAS, dengan demikian donatur telah membatu aktifitas zakat. Opentable yaitu kegiatan yang dilakukan dengan cara membuka stand BAZNAS, yang biasa dilaksanakan di si tempattempat ramai, mall atau event-event tertentu yang didalamnya terkumpul banyak orang. Kegiatan ini dua tujuan penting. Pertama, sosialisasi zakat, infak dan sedekah dengan membangun brand awareness kepada para pengunjung akan pentingnya berbagi dan memberi. Kedua, penggalangan dana dari para pengunjung, dengan membuka layanan dana zakat, infak dan sedekah. ${ }^{16}$

Selain itu LAZ Daarut Tauhid juga menerapkan model fundraising zakat, infak dan sedekah melalui kencleng
Pendekatan Business Model Canvas, Jurnal Humam Falah, Volume 4 No. 2 Juli -Desember 2017 h. 281

${ }^{16}$ Ahmad Nursamsi, Manajemen Penghimpunan Dana ZIS pada Badan Amil Zakat Nasional (BAZNAS), UIN Syarif Hidayatullah, Jakarta, 2014, h. 52 
umat, bekerkasama dengan radio paramuda 93.9 FM, kampanye di radio dan religius fund. Dinamakan demikian karena pengumpulan dana dilakukan dalam kegiatan keagamaan seperti pengajian. Selain itu menggunakan direct mail, media campaign, membership, corporate fund dan earned incame (unit usaha yang dikelola dari berbagai sumbangan yang diberikan oleh perusahaan, jemput ZIS dan Tamsil (Tim Silaturrahmi) dimana petugas langsung menemui muzakki dan menerbitkan media cetak bernama majalah swadaya dan leaflet, dan zakat juga dikampanyekan lewat website dan facebook. ${ }^{17}$

\section{Analisis Model Fundraising Zakat,} Infak dan Sedekah

Model fundraising zakat yang telah dilakukan oleh lembaga-lembaga zakat secara garis besar di bagi menjadi dua bentuk yaitu penghimpunan zakat secara langsung kepada muzakki dan kedua penghimpunan zakat secara tidak langsung.

Pertama, penghimpunan zakat secara langsung kepada muzakki dirasakan lebih maksimal dalam memberikan pelayanan dan kemudahan bagi muzakki, dimana petugas

${ }^{17}$ N. Oneng Nurul Badriyah, Strategi Penghimpunan Dana Sosial Ummat pada Lembagalembaga Filantropi di Indonesia (Studi Kasus Dompet mendatangi secara langsung muzakki yang akan membayar zakat, infak maupun sedekah. Biasanya muzakki telah mempersiapkan sejumlah harta yang akan dikeluarkan. Akan tetapi dalam pelaksanaannya terdapat kelemahan karena keterbatasan petugas dan luasnya wilayah pengumpulan zakat membuat para petugas pada lembaga zakat harus mendatangi muzakki satu persatu. Hal ini akan sulit dilakukan jika petugas masing-masing lembaga jumlahnya sedikit atau berbanding terbalik dengan jumlah muzakki dan wilayah pengumpulan zakat. Kemudian dari sisi operasional akan menghabiskan biaya bagi petugas yang akan melaksanakan tugas pengumpulan zakat. Dari aspek komunikasi pengumpulan zakat secara langsung akan membangun komunikasi dan emosional tersendiri dengan muzakki, karena muzakki dapat berkomunikasi secara langsung dengan petugas dan bisa juga melakukan konsultasi terkait harta yang akan dizakatkan maupun program pengelolaan zakat yang diterapkan pada sebuah lembaga. Hal ini dapat meningkatkan motivasi dan kepercayaan muzakki terhadap lembaga pengelola

Peduli Umat Daarut Tauhid, Dompet Duafa Republika, BAZNAS dan BAZIS DKI Jakarta. Jurnal Li Falah volume 1 Nomor 1 Juni 2016, ejournal.iainkendari.ac.id 
zakat untuk terus menyalurkan zakat pada lembaga zakat.

Membangun kepercayaan muzakki sangat perlu dilakukan untuk kontiunitas pembayaran zakat, baik zakat fitrah maupun maal. Apabila pembayaran zakat maal dapat dilakukan setiap tahun ketika harta muzaki mencapai nisab, maka hal ini sangat membantu kesinambungan pengelolaan zakat khususnya produktif. Karena akan banyak mustahik yang bisa merasakan manfaat dari distribusi zakat terutama dalam meningkatkan kesejahteraan dan ekonomi muzakki.

Kedua, penyaluran zakat secara tidak langsung dengan menggunakan media cetak maupun elektronik. Model ini dirasa lebih efektif dan efisien dari aspek waktu dan petugas atau amil yang akan mengumpulkan zakat.

Model ini memudahkan masyarakat yang akan menyalurkan dana zakat, infak maupun sedekah dengan melihat dan membaca informasi yang ada di brosur cetak maupun eektronik. Karena di dalam brosur akan tertera jenis harta yang wajib dizakatkan, cara penghitungan zakat dan program pendistribusian maupun pendayagunaan yang telah disiapkan oleh masingmasing lembaga zakat.

Selain itu model penyaluran tidak langsung melalui sosialisasi di media sosial juga sangat efektif, karena kondisi zaman sekarang media sosial banyak digunakan oleh lembaga-lembaga zakat untuk mempromosikan program penghimpunan dan pendayagunaan zakat. Karena sebagian besar masyarakat telah menggunakan media sosial yang bisa diakses kapan dan dimana saja. Menjadikan model ini cukup efektif digunakan dalam mensosialisikan zakat. Selain itu masyarakat juga bisa berkomunikasi secara langsung kepada amil atau pengelola zakat pada masingmasing lembaga terkait informasi yang telah disampaikan. Untuk sebagian lembaga zakat sudah menyediakan layanan group melalui media sosial seperti whatsapp, instagram dan facebookdan twiteer.

Lembaga zakat khususnya BAZNAS dapat melakukan kerjasama dengan instansi pemerintah dan swasta untuk melakukan kegiatan sosialisasi maupun edukasi kepada pegawai atau karyawan di masing-masing lembaga, kerena kegaiatan ini telah diintruksikan oleh Presiden dan beberapa peraturan pemerintah, kementerian agama maupun peraturan Badan Amil Zakat Nasional yang mengatur tentang pengelolaan BAZNAS yang termasuk juga pengaturan tentang pengumpulan zakat, infak dan sedekah. 
Tugas lembaga zakat dalam menyalurkan informasi kepada masyarakat sebagaimana tercantum dalam Instruksi Presiden Republik Indonesia nomor 3 tahun 2014 tentang Optimalisasi Pengumpulan Zakat di kementerian/Lembaga, Sekretariatan Jenderal lembaga Negara, Sekretariat Jenderal Komisi Negara, Pemerintah Daerah, Badan Usaha Milik Negara dan Badan Usaha Milik Daerah melalui Badan Amil Zakat Nasional, dimana dijelaskan bahwa lembaga pemerintah dan BUMN melakukan koordinasi dengan Badan Amil Zakat Nasional dengan cara melakukan sosialisasi dan penyebaran informasi mengenai zakat kepada seluruh pegawai/karyawan yang beragama Islam di lingkungan instansi masing-masing; dan mendorong dan memfasilitasi pegawai/ karyawan yang beragama Islam di lingkungan instansi masing-masing untuk membayar zakat melalui Badan Amil Zakat Nasional.

Kelemahan model ini adalah karena penyampaian informasi zakat, infak dan sedekah secara tidak langsung, kadangkala sebagian masyarakat belum memperhatikan secara jelas informasi brosur cetak maupun media elektronik. Sehingga informasi yang diterima belum direspon secara langsung oleh masyarakat. Selain itu masyarakat juga sering menunda pembayaran zakat karena tidak ada yang mengingatkan secara khusus untuk melakukan pembayaran zakat, karena kesibukan dari aktivitas masyarakat berbeda-beda, membuat informasi yang disampaikan kurang diperhatikan, sehingga tidak ada tindak lanjutnya. Untuk sebagian masyarakat membutuhkan jadwal atau waktu tertentu untuk membaca brosur dan informasi, sehingga harapan dari pengelolala zakat agar muzakki menyalurkan zakat belum dapat terealisasi secara maksimal. Karena itu untuk lembaga dapat menyiapkan sumber daya manusia yang bisa mengatasi masalah tersebut dengan membuat program-program aplikasi yang memudahkan muzakki dan teradwal serta terpantau pelaksanaannya setiap saat. Sehingga muzakki sewaktu akan mencari informasi bisa langsung menghubungi petugas amil zakat yang ada atau membuka aplikasi web yang ada pada lembaga zakat, yang bisa menjawab semua kebutuhan informasi terkait zakat, infak dan sedekah.

Selain itu, badan amil zakat juga harus bersikap proaktif kepada masyarakat melalui kegiatan 
komunikasi, informasi dan edukasi. ${ }^{18}$

Seperti workshop, seminar dan kegiatan silaturahmi lainnya untuk menjalin hubungan baik dengan masyarakat. Hal ini dilakukan untuk meningkatkan kepercayaan dan antisias masyarakat agar selalu membayar zakat sebagai perwujudan ketaatan mareka kepada Allah atas semua rezeki yang ditelah diberikan dan memberikan hak para mustahik zakat dari harta yang dimiliki oleh muzakki.

\section{KESIMPULAN}

Model fundrasing zakat, infak dan sedekah yang diterapkan oleh lembaga zakat saat ini sudah variatif dan inovatif, namun perlu diperbaiki dari aspek sumber daya manusia dan sistem informasi melalui aplikasi yang mudah diakses oleh masyarakat, agar bisa memberikan pelayanan maksimal kepada muzakki untuk tertarik membayar zakat dan kontiunitas, sebagai tolak ukur dari kesuksesan pengelolaan zakat, salah satunya dengan optimalisasi pengumpulan zakat dengan merujuk pada potensi zakat yang ada masingmasing wilayah pengelola zakat.

\section{DAFTAR PUSTAKA}

Amin, Analisis Strategi Penghimpunan Dana dalam Mencapai Target Penerimaan Dana Zakat: Studi pada LAZ Dompet
Duafa Cabang Jawa Timur. PDF.uinsby.ac.id

Aziz, Muhammad, Regulasi zakat di Indonesia; Upaya menuju Pengelolaan zakat yang Profesional, Jurnal al Hikmah, Vol 4 No. 1 tahun 2014, ejurnal.kopertais4.or.id

Arifin, Gus, Zakat, Infak Sedekah, Jakarta, Elex Media Komputindo, 2016

Badriyah, N. Oneng Nurul, Dinamika Aspek Hukum Zakat dan Wakaf di Indonesia, jurnal Ahkam Vol. XVI, no. 2 tahun 2016, journal.uinjkt.ac.id

Badriyah, N. Oneng Nurul, Strategi Penghimpunan Dana Sosial Ummat pada Lembaga-lembaga Filantropi di Indonesia (Studi Kasus Dompet Peduli Umat Daarut Tauhid, Dompet Duafa Republika, BAZNAS dan BAZIS DKI Jakarta. Jurnal Li Falah volume 1 Nomor 1 Juni 2016, ejournal.iainkendari.ac.id

Coryna, Ita Aulia, Formulasi Strategi Penghimpunan Dana Zakat oleh Badan Amil Zakat Nasional. Repository,sb.ipb.ac.id

CiD,DDR, Pebs-FEUI, Zakat dan Pembangunan; Era Baru Zakat Menuju Kesejahteraan Umat, Jakarta, 2008 dalam Amiruddin, Model-model Pengelolaan Zakat di Dunia Muslim, ejurnal.iain-tuungagung.ac.id

Dahlan, Abdul Aziz, dkk, Ensiklopedi Hukum Islam, Jakarta, Van Hoeve, 1997

Fajri, Em Zul dan Ratu Aprilia Senja, Kamus Lengkap Bahasa Indonesia, tt: Fajar Difa Publisher, t.th

Instruksi Presiden Republik Indonesia nomor 3 tahun 2014 tentang Optimalisasi Pengumpulan Zakat di kementerian/Lembaga, Sekretariatan Jenderal lembaga Negara, Sekretariat Jenderal Komisi Negara, Pemerintah

\footnotetext{
${ }^{18}$ Penjelasan Pasal 12 ayat 1 Undang-undang RI Nomor 38 tahun 1999 tentang Pengelolaan Zakat
} 
Daerah, Badan Usaha Milik Negara dan Badan Usaha Milik Daerah melalui Badan Amil Zakat Nasional

Keputusan Presiden Republik Indonesia nomor 8 tahun 2001 tentang Badan Amil Zakat Nasional

Munawir, Ahmad Warson, Kamus AlMunawir Arab-Indonesia Terlengkap, (Surabaya: PustakaProgresif, 1997

Nursamsi, Ahmad, Manajemen Penghimpunan Dana ZIS pada Badan Amil Zakat Nasional (BAZNAS), UIN Syarif Hidayatullah, Jakarta, 2014

Purnamasari, Dian dan Achmad Firdaus, Analisis strategi Penghimpunan Zakat dengan Pendekatan Business Model Canvas, Jurnal Humam Falah, Volume 4 No. 2 Juli -Desember 2017

Peraturan Pemerintah RI nomor 14 tahun 2014 tentang pelaksanaan Undang-undang nomor 23 tahun 2011 tentang Pengelolaan Zakat

Qardhawi, Yusuf, FiqhZakat,Terj. Salman Harun, el.al,Jakarta,LiteraAntar Nusa, 2002

Rusyd, Ibnu, BidayatulMujatahid,penerjemah Imam Ghazali Said dan Ahmad Zaidun, Jakarta,PustakaAmani, 2007

Undang-undang Republik Indonesia Nomor 38 Tahun 1999 tentang Pengelolaan Zakat

Undang-undang nomor 23 tahun 2011 tentang Pengelolaan Zakat

Waluyo, Sabar, Analisis Strategi Fundraising Lembaga Amil Zakat Infak Shadaqah Muhammadiyah (LAZISMU) Ajibarang Kabupaten Banyumas dalam Mendapatakan Muzaki, 2016, IAIN Purwokerto 